\title{
Zachowanie naturalnego środowiska przyrodniczego w ramach współczesnych rozwiązań architektonicznych. Świerkocin na Mazurach
}

\section{Preserving ecological balance in modern architecture solutions. Świerkocin in Masuria}

\begin{abstract}
Streszczenie
Celem pracy jest poszerzenie świadomości projektantów dotyczącej wpływu obiektu architektonicznego na różnorodność biologiczną naturalnych ekosystemów na konkretnym przykładzie środowiska miejscowości Świerkocin. W artykule przedstawiono rozwiązania architektoniczne z zakresu ochrony przed zanieczyszczeniem świetInym i krajobrazu. Uniwersalność omówionych rozwiązań pozwala na ich zastosowanie zarówno w Świerkocinie, jak i w innych miejscach o podobnej charakterystyce.
\end{abstract}

Słowa kluczowe: bioróżnorodność, małe miejscowości, ochrona środowiska, zanieczyszczenie świetlne, zanieczyszczenie krajobrazu, projektowanie zrównoważone, green architecture

\begin{abstract}
The purpose of the article is to enhance the architect's knowledge about the impact of the building on biodiversity. The presented topic is based on a example of small village Świerkocin. The architectural solutions presented here provide a general guidance on how to reduce unnecessary light and land pollution. The proposed actions are crafted for various environments. They can be implemented in Świerkocin, as well as in the other similar places.
\end{abstract}

Keywords: biodiversity, small villages, environmental protection, light pollution, land pollution, sustainable design, green architecture 


\section{WSTĘP}

Różnorodność biologiczna to „zmienność żywych organizmów zamieszkujących wszystkie środowiska oraz zmienność systemów ekologicznych, których częścią są te organizmy" (Konwencja o różnorodności biologicznej, 2002). Jej istnienie jest kluczowe dla zachowania układów podtrzymujących życie w całej biosferze, dlatego należy chronić naturalne lub praktycznie nieprzekształcone siedliska. Utrata nawet jednego może doprowadzić do wymarcia całego gatunku. Dobra znajomość problemu i współczesne środki architektoniczne dają nam możliwości zapewnienia im bezpieczeństwa. Poszukiwanie optymalnych rozwiązań powinno być zawsze poparte dokładną analizą terenową przypadku.

Celem artykułu jest przedstawienie potencjalnych zagrożeń dla środowiska, związanych z rozbudową małych miejscowości, a także opisanie rozwiązań architektonicznych, które mogą neutralizować te niebezpieczeństwa. Ta tematyka jest wyjątkowo istotna w przypadku miejsc, gdzie tkanka przyrodnicza jest praktycznie nienaruszona. Przykładem miejscowości, w której znajdziemy wiele nieprzekształconych siedlisk, jest Świerkocin. Jest to wieś położona w województwie warmińsko-mazurskim, w powiecie olsztyńskim, w gminie Olsztynek. Zakres przeprowadzonych badań obejmuje jej teren oraz całość gminy. Rozpoznanie problemu opiera się na badaniach in situ, a także na analizie krytycznej literatury naukowej oraz źródeł internetowych.

Świerkocin ma duży potencjał turystyczny i będzie się rozwijał w tym kierunku. Oznacza to też poszerzenie istniejącej tkanki zabudowy. $Z$ tego powodu szczególnie istotny jest odpowiedni dobór rozwiązań architektonicznych, uwzględniających ochronę przyrody. Uniwersalność przedstawionych rozwiązań pozwala na ich zaadaptowanie w wielu miejscach w Polsce.

\section{2. ŚWIERKOCIN}

Współczesny Świerkocin ma charakter letniskowy. Sektor turystyczny stanowi w tym rejonie jedną z najważniejszych gałęzi gospodarki. Aktualnie mieszka tutaj 69 osób ${ }^{1}$, a większość budynków przeznaczona jest do wynajęcia przez turystów. We wsi dominuje zabudowa mieszkaniowa jednorodzinna niska. Rzadziej występują zespoły zagrodowe, choć miejscowy plan przewiduje zwiększenie ich liczby. Najwięcej budynków zlokalizowanych jest przy głównej drodze, ale ogólnie zabudowa jest rozproszona. Budownictwo jest drewniane bądź murowane. Charakteryzuje się użyciem konkretnych materiałów, w przypadku domów murowanych są to zwykle pomarańczowa dachówka ceramiczna i biały tynk. Elewacje uwidaczniają również często tradycyjny mur pruski. Większość terenów miejscowości jest niezabudowana, zielona. Bardzo rzadko dostrzega się ingerencje człowieka w układ

1 https://www.polskawliczbach.pl/Wsie-warminsko_mazurskie (dostęp: 16.04.2021). 

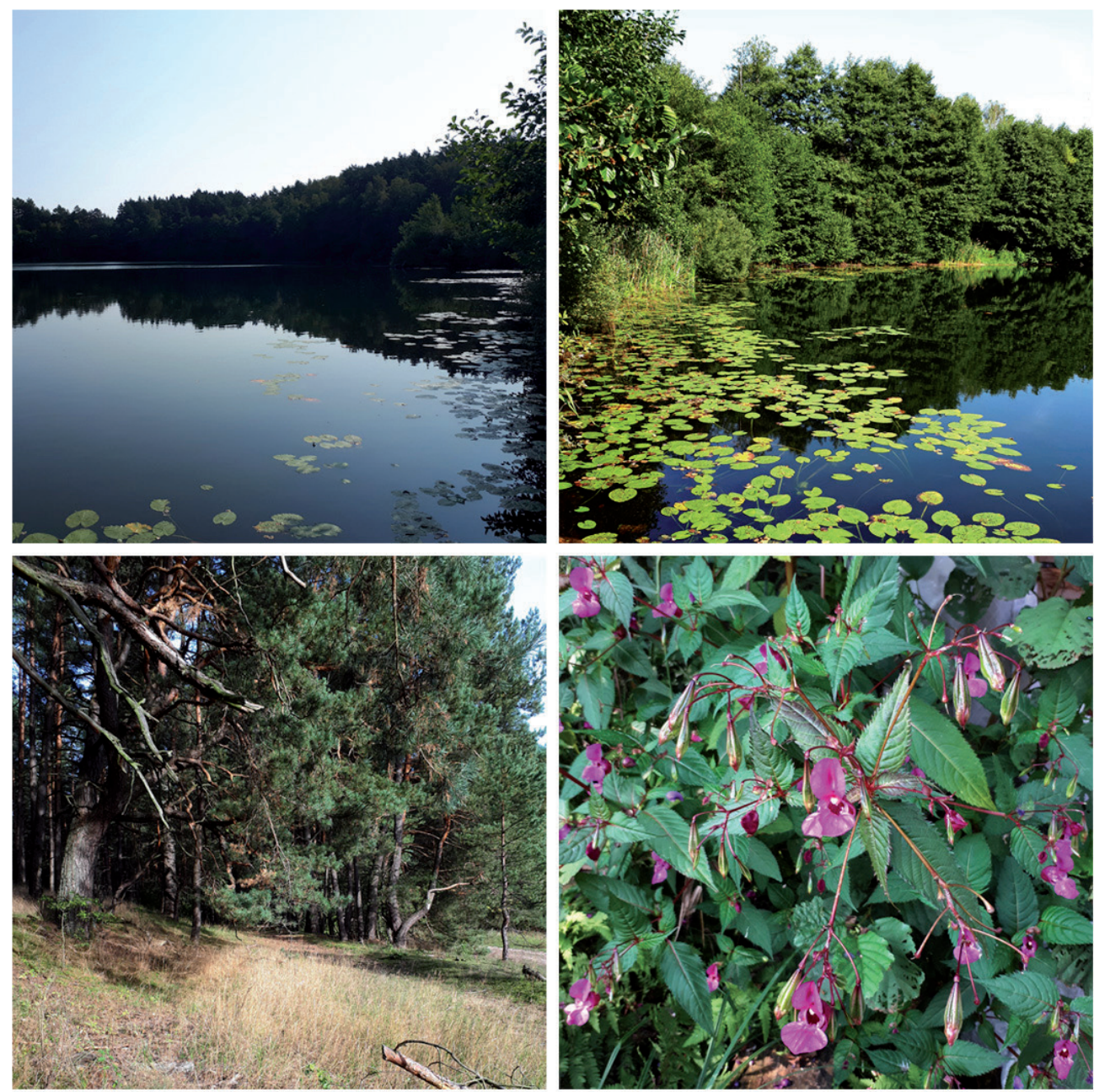

II. 1-4. Naturalny krajobraz w Świerkocinie i Swaderkach. Fot. autor

lasów, jezior, rzek i łąk, dzięki czemu zachowane są ich oryginalne kształty i struktura. Stosunek ilości terenów zielonych do zabudowanych pokazano w ramach analizy funkcjonalnej dla tego terenu (il. 5).

Obszary leśne zajmują blisko 52\% powierzchni gminy Olsztynek. Skupiska drzew występują w zwartych kompleksach. Są to przede wszystkim bory świeże i mieszane. Wśród rosnących tu gatunków najpopularniejsza jest sosna (stanowi aż 80\% drzewostanu), ale na opisywanym terenie rosną także świerki, modrzewie, dęby, brzozy, olchy oraz buki. Wśród miejscowej fauny najbardziej różnorodne i najliczniej reprezentowane są ptaki. Ornitolodzy stwierdzili obecność blisko 233 różnych gatunków. Na terenie gminy gniazdują nawet 
odmiany zagrożone w skali świata, takie jak orlik bielik i derkacz. Można tu także spotkać błotniaka łąkowego, bociana czarnego, rybołowa, orlika krzykliwego, puchacza, sowę uszatą, dzięcioła czarnego, zimorodka, dudka, kormorana czy czaplę siwą². Takie bogactwo i niezwykłą różnorodność ptasiej fauny należy szczególnie chronić, a projektowanie architektury powinno to uwzględniać.

-...Granica miejscowości

Działka projektowa - teren pod zabudowę zagrodowa z możliwością realizacji funkcji agroturystycznej

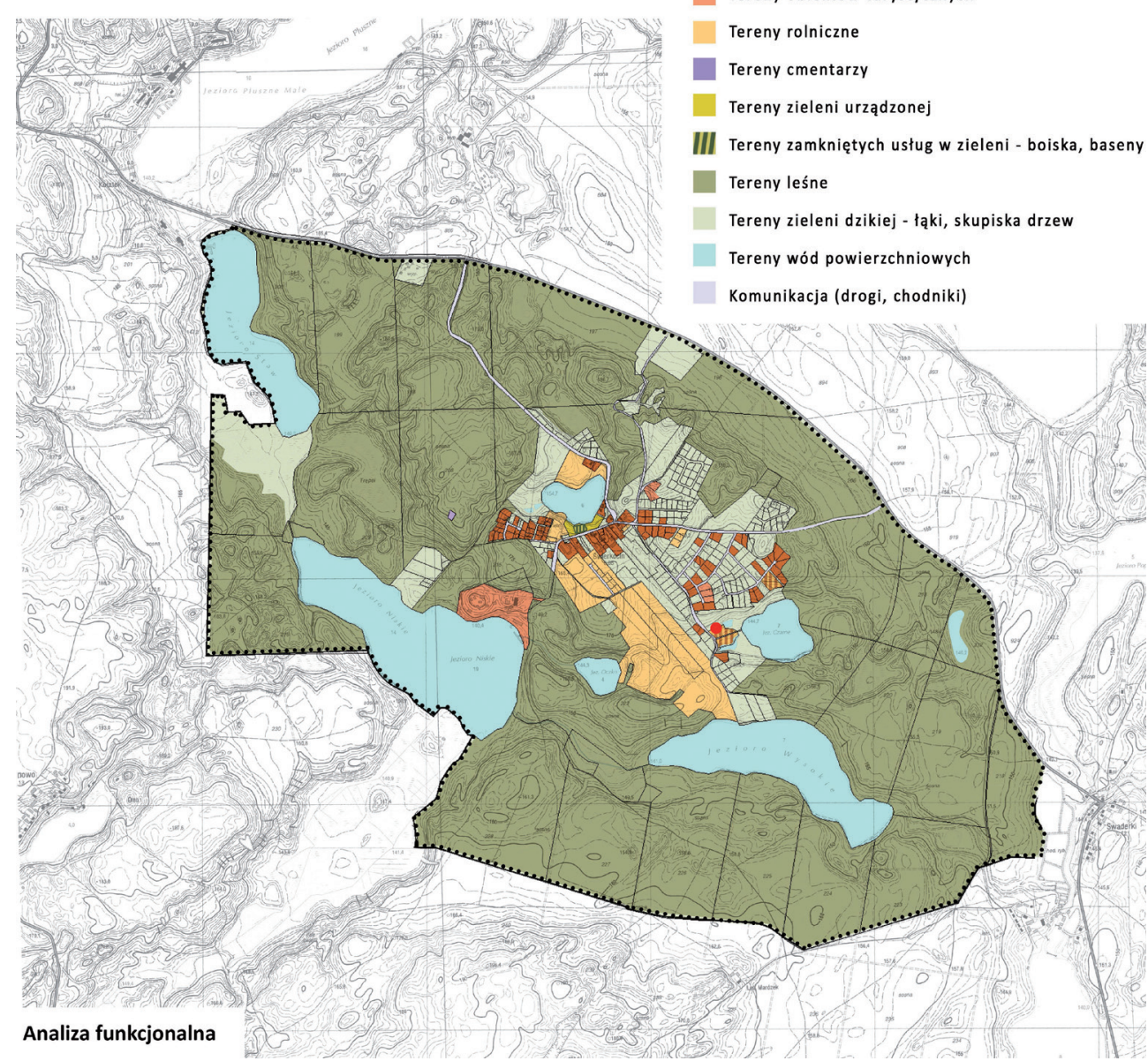

II. 5. Mapa przestawiająca wyniki analizy funkcjonalnej. Proj. autor

Tereny zabudowy mieszkaniowej jednorodzinnej

VII Tereny zabudowy zagrodowej z możliwością realizacji funkcji agroturystycznej

Tereny obiektów turystycznych

Tereny rolniczne

eny cmentarzy

Tereny zamkniętych usług w zieleni - boiska, baseny Tereny leśne

Tereny zieleni dzikiej - łąki, skupiska drzew

Tereny wód powierzchniowych 
Fauna leśna to nie tylko ptaki. Lasy zamieszkują również inne cenne zwierzęta, takie jak sarny, jelenie, dziki, borsuki, lisy czy wiewiórki. W bezpośrednim sąsiedztwie zbiorników wodnych występują natomiast bobry, piżmaki, wydry oraz wiele płazów - traszki zwyczajne, traszki grzebieniaste, żaby wodne, ropuchy zwyczajne, ropuchy zielone i kumaki nizinne. Można wreszcie spotkać tutaj gady, między innymi żółwie błotne oraz jaszczurki³.

Ponad 70\% tkanki leśnej gminy Olsztynek objęte zostało ekologicznym systemem obszarów chronionych. Na terenie gminy znajduje się również wiele rezerwatów przyrody. Planuje się powiększanie tych przestrzeni ${ }^{4}$.

Głównym uwarunkowaniem sprzyjającym rozwojowi gminy Olsztynek, a w tym miejscowości Świerkocin, jest różnorodność jej środowiska naturalnego. Są to cenne zasoby dziedzictwa przyrodniczego, które stanowią też czynnik przyciągający turystów.

\section{ZAGROŻENIA DLA ŚRODOWISKA NATURALNEGO ŚWIERKOCINA}

Informacje zawarte $\mathrm{w}$ studium zagospodarowania przestrzennego gminy Olsztynek wskazują, że największe zagrożenie dla jej środowiska wynika z niekontrolowanego rozwoju rolnictwa przemysłowego. Problemem jest fakt, że większość terenów nie jest objęta miejscowym planem zagospodarowania. Polityka przestrzenna gminy powinna skupić się przede wszystkim na ograniczeniu szkodliwego wpływu rolnictwa, ale przez braki w planowaniu jest to utrudnione. W związku z tym głównym celem staje się zabezpieczenie cennych wód gruntowych i powierzchniowych. Podstawowym warunkiem tej ochrony jest rozbudowa powstającej sieci kanalizacyjnej (Studium uwarunkowań..., 2020).

Zagrożeniem dla środowiska naturalnego Świerkocina są zwłaszcza zanieczyszczenia. Najbardziej niebezpieczne są te pochodzące z przemysłu rolniczego, ale nie tylko takie należy wziąć pod uwagę. Domy jednorodzinne i zespoły letniskowe także są ich źródłem. Poniżej wyszczególnione zostały dwa podstawowe zagrożenia dla środowiska, związane z projektem architektury: zanieczyszczenie świetlne i krajobrazu.

\section{ZANIECZYSZCZENIE ŚWIETLNE}

Sztuczne oświetlenie jest nieodłącznym elementem projektowym w każdym budynku. Jego wykorzystanie pozwala na dowolne ustalanie godzin naszych aktywności i sprawia, że możemy funkcjonować całodobowo. Jednakże taki uniwersalny tryb życia powoduje, że w naszym otoczeniu pojawia się zjawisko nadmiernego oświetlenia. Jest to problem

3 https://olsztynek.pl/miasto-i-gmina-olsztynek/przyroda/fauna-i-flora/ (dostęp: 7.12.2020).

4 https://www.polskawliczbach.pl/Wsie-warminsko_mazurskie (dostęp: 16.04.2021). 
przede wszystkim miejskich aglomeracji, gdzie łatwo możemy zauważyć tzw. zanieczyszczenie świetlne atmosfery - wystarczy obserwować nocne niebo. Można też wykorzystać skalę Bortle’a, aby sprawdzić, jak ciemne ono jest. W mieście niebo spowite jest pomarańczowo-szarą poświatą i często nie jesteśmy w stanie dostrzec żadnych gwiazd - będzie to klasa 8 bądź 9. Natomiast w takiej miejscowości jak Świerkocin doskonale widoczne są złożoność Drogi Mlecznej, Galaktyka Trójkąta czy niektóre gromady kuliste. To oznacza, że możemy mieć do czynienia z klasą 3. Obserwacja takiego czystego nieba dostarcza wyjątkowych doznań natury estetycznej. Na naszej planecie jest coraz mniej miejsc, gdzie możemy ujrzeć ciemne niebo. Nie ulega więc wątpliwości, że warto chronić takie przestrzenie przed zanieczyszczeniem świetlnym. Nie jest to oczywiście łatwe, biorąc pod uwagę, że może być ono przenoszone na duże odległości. Dzieje się tak przez odbijanie się fal świetlnych od chmur (Siedlecki, 2016: 125-130). Jako projektanci architektury możemy jednak działać, przede wszystkim lokalnie, w celu zapobiegania temu zjawisku.

Nadmierne sztuczne oświetlenie to zagrożenie nie tylko dla atmosfery, ale też dla organizmów żywych. Obecnie bardzo popularne są diody LED. Związane jest to z ich energooszczędnością i długą żywotnością. Wadą tych diod jest emitowanie światła przede wszystkim o krótkich falach oraz widma o zimnym odcieniu - niebieskim bądź fioletowym. Niebieski znacznie różni się od naturalnej barwy światła słonecznego. Kolor ten blokuje u ssaków wytwarzanie melatoniny, czyli powoduje bezsenność (Siedlecki, 2016: 125-130). Wykazano także, że światło niebieskie i czerwone, czyli najbardziej skrajne długości fal, mają często intensywne oddziaływanie na owady. Powodują ich przyciąganie i aktywność ruchową lub przeciwnie, straszą i paraliżują. Barwy pośrednie, takie jak żółta i zielona, nie mają tak istotnego wpływu na bezkręgowce (Marcinowska, Tęgowska, 2015: 589-597). Intensywne oświetlenie wpływa zatem na zmianę naturalnej aktywności ruchowej fauny. Niektóre gatunki będą gromadzić się na obszarach, gdzie wcześniej nie występowały, a inne będą je opuszczać.

\subsection{PRZYKŁADY SZKÓD PRZYRODNICZYCH WYNIKAJĄCYCH Z ZANIECZYSZCZENIA ŚWIATŁEM}

Zanieczyszczenie świetlne ma wpływ na konkretne zmiany w zachowaniu środowiska naturalnego. Może powodować między innymi:

\subsubsection{MIGRACJE GATUNKÓW}

Przykładem tworzenia się takiego zaburzonego nagromadzenia migracyjnego może być zooplankton, występujący w zbiornikach wodnych. Pojawienie się oświetlenia sztucznego w pobliżu zbiornika powoduje, że te zespoły organizmów migrują w głąb zbiornika z obawy przed drapieżnikami, czego skutkiem jest zwiększona przeżywalność glonów przy powierzchni wód. To z kolei wywołuje ich przyspieszony zakwit, ogólne obniżenie jakości wody i powolne zarastanie zbiornika (Tałanda, 2015: 611-616). 
W Świerkocinie występuje wiele chronionych jezior, więc to zagrożenie powinno być wzięte pod uwagę przy projektowaniu oświetlenia zewnętrznego budynku i działki.

\subsubsection{ZABURZONY CYKL REPRODUKCJI}

Przykładem innej zmiany naturalnej aktywności ruchowej jest przyciąganie przez lampy LED wielu gatunków owadów. Niektóre kwiaty kwitną nocą i zapylane są przez ćmy. Sztuczne oświetlenie przyciąga te stworzenia, powodując zaburzenie orientacji w terenie, a w rezultacie uniemożliwiając zapylenie (Marcinowska, Tęgowska, 2015: 589-597). To zjawisko może doprowadzić do wyginięcia gatunków roślin. Podobnie zagrożone przez zjawisko zaburzenia orientacji w terenie są też między innymi świetliki. Lokalizacja samic przez samce staje się bowiem utrudniona przez zbyt duże natężenie światła nocą (Tałanda, 2015: 611-616).

\subsubsection{UŁATWIENIE DLA DRAPIEŻNIKÓW}

Niektóre zwierzęta wykorzystują ciemność nocy jako naturalną sferę ochronną przed drapieżnikami. Przez sztuczne oświetlenie w nocy, ograniczające taką sferę, zostaje zaburzony łańcuch pokarmowy, z największą korzyścią dla drapieżnika szczytowego (Tałanda, 2015: 611-616).

\subsection{SPOSOBY REDUKCJI ZANIECZYSZCZEŃ ŚWIETLNYCH W RAMACH PROJEKTU ARCHITEKTONICZNEGO}

Istnieje wiele prostych sposobów na ograniczenie produkcji zanieczyszczenia świetlnego w ramach projektu architektonicznego. Można zaproponować następujące:

- Odpowiednie instalacje. Dobrym rozwiązaniem jest instalacja czujników ruchu w miejscach, gdzie światło sztuczne jest nam potrzebne okazjonalnie. Unikniemy sytuacji, w których teren jest niepotrzebnie oświetlony całą noc.

- Unikanie tworzenia punktów światła rozproszonego. Odsłonięte żarówki oraz kuliste źródła światła mogą być mylące dla owadów. Dla niektórych będą one na przykład łudząco podobne do Księżyca (Marcinowska, Tęgowska, 2015: 589-597). Warto więc wykorzystać takie obudowy lamp, które pozwolą na całkowitą kontrolę kierunku i zasięgu padania strumienia światła.

- Zastosowanie świateł o neutralnych długościach fali. Pożądane byłoby unikanie stosowania światła o skrajnych długościach fal, takich jak niebieskie i czerwone. Pośrednie, ciepłe barwy o takich odcieniach jak żółty czy zielony nie mają tak istotnego wpływu na większość zwierząt. Nie jest to regułą, ale dotyczy znaczącej liczby gatunków.

- Unikanie światła spolaryzowanego. Niektóre materiały o gładkiej powierzchni powodują zwiększony efekt polaryzacji światła. Światło odbite od wody, śniegu, lodu, ale też mokrego asfaltu czy ciemnej elewacji budynku tworzy oślepiającą poświatę. Niektóre zwierzęta, na przykład pszczoły, potrafią określać stopień polaryzacji światła i wykorzy- 
stują go do orientacji w terenie nawet w pochmurne dni (Bobrowski, 2021). Dlatego jeśli w ramach projektu nowego siedliska chcielibyśmy zlokalizować pasiekę, dobrze jest zadbać o odpowiedni dobór materiałów wykończeniowych.

- Wykorzystanie światła naturalnego. Minimalną i maksymalną wielkość okien w budynkach określają odpowiednie przepisy prawa budowlanego. Wielkości przeszkleń powinny być dostosowane do orientacji budynku względem kierunków świata, a najlepiej poparte analizą energetyczną. Jeśli pieczołowicie zadbamy o ten aspekt, jesteśmy w stanie ograniczyć zużycie światła sztucznego przez użytkowników. Pokoje będą dłużej doświetlone i nie będzie w nich ciemnych punktów. Światło naturalne może tworzyć dużo bardziej różnorodny klimat niż sztuczne, bo jego wygląd i natężenie zmienia się w zależności od pory dnia i roku.

\section{ZANIECZYSZCZENIA KRAJOBRAZU}

Kolejnym rodzajem zagrożenia środowiska jest zanieczyszczenie krajobrazu. Intensyfikacja rolnictwa wywiera istotny negatywny wpływ na jego różnorodność. Grunty dobrej jakości poddane są uprawie, podczas gdy grunty słabsze pozostają niezagospodarowane, często zalesione. Przez położenie nacisku na wzrost produkcji rolnej dochodzi do zanikania naturalnych struktur (Tryjanowski i in., 2011: 113-119). Jest to problem także w gminie Olsztynek, gdzie niekontrolowany rozwój rolnictwa zaczyna być zauważalny. Tereny rolne to pola o bardzo jednolitym posadzeniu, co ogranicza bioróżnorodność, a w rezultacie prowadzi do zubożenia krajobrazu. W Świerkocinie mamy do czynienia z praktycznie nieprzekształconym otoczeniem. Większość terenów to lasy, a istniejąca zabudowa jest bardzo tradycyjna. Dlatego rozwój ekosystemów lasów powinien być wspomagany przez zrównoważone projekty zagospodarowania terenu. Należy też się zastanowić, jakie elementy przestrzenne wsi powinny zostać zachowane, a jakie powinny być ograniczane.

\subsection{SPOSOBY REDUKCJI ZANIECZYSZCZEŃ KRAJOBRAZU W RAMACH PROJEKTU ARCHITEKTONICZNEGO}

W ramach ochrony przed tym zanieczyszczeniem można wykorzystać rozwiązania i zasady architektoniczne oraz z pogranicza tej dziedziny, takie jak:

\subsubsection{TWORZENIE WYSP ŚRODOWISKOWYCH}

Zwiększające się powierzchnie pól o jednolitym posadzeniu mają wpływ na różnorodność ekosystemu. Jest to między innymi przeszkoda dla naturalnych zapylaczy - pszczół i trzmieli. Podstawowym czynnikiem wpływającym na ich liczbę jest baza pokarmowa, ograniczana przez brak zróżnicowania posadzeń. Brak dostatecznej ilości zapylaczy powoduje roślinne 
zubożenie terenu, a w rezultacie degradację krajobrazu (Bobrowski, 2021). Rozwiązaniem tego problemu może być tworzenie wysp środowiskowych. Są to ekosystemy o zbliżonym charakterze, położone w zupełnie obcym, niesprzyjającym otoczeniu (będą to np. niewielkie powierzchnie leśne, zadrzewienia śródpolne, łąki i jeziora) (Bobrowski, 2021).

\subsubsection{STOSOWANIE ZASAD KRYTYCZNEGO REGIONALIZMU}

Budynek sam w sobie jest już zmianą istniejącego krajobrazu. Projektując go, powinniśmy starać się podtrzymać indywidualne i lokalne cechy architektury danego rejonu. Kontekst lokalności należy traktować szeroko. W wypadku Świerkocina są to nie tylko tradycyjne zabudowania, ale przede wszystkim naturalna tkanka przyrodnicza. Krytyczne spojrzenie polega na analizie ograniczeń kontekstualnych wraz z zachowaniem współczesnego myślenia dotyczącego rozwiązań programowych i materiałowych. Stosowanie tej definicji krytycznego regionalizmu (Frampton, 2017: 11-21) pozwoli nam na zaprojektowanie budynku, który dodatkowo wzbogaci krajobraz.

\section{POSZUKIWANIE NOWYCH METOD PROJEKTOWYCH CHRONIĄCYCH ŚRODOWISKO}

Przedstawione sposoby ograniczania wpływu zanieczyszczeń środowiskowych mogą znaleźć odzwierciedlenie w istniejących już projektach. Wyspa środowiskowa może zostać wykorzystana jako element architektoniczny. Przykładem założenia, które wykorzystuje podobny pomysł, jest eksperymentalny projekt Baubotanik Tower (il. 6). Jest to budynek skonstruowany z żyjących roślin. Jego struktura ma być wspierana przez stalową konstrukcję aż do momentu samostabilizacji ${ }^{5}$.

Nie tylko jednak najbardziej współczesne projekty i eksperymenty mogą stanowić zrównoważone wzorce projektowe. Przyjazne środowisku rozwiązania znajdziemy też w architekturze modernistycznej, dziś należącej już do projektowego kanonu. Ten kierunek kojarzy się z racjonalnością i funkcjonalnością. A co za tym idzie - z racjonalnym wykorzystaniem światła dziennego. Architektem, który bardzo dobrze opanował tę sztukę, był Louis Kahn. Można znaleźć wiele przykładów jego projektów, które nie tylko zapewniają odpowiedni dostęp do światła dziennego, ale też wykorzystują jego walor jako środek artystyczny (il. 7 i 8).

Nurt green architecture proponuje wiele rozwiązań, które starają się zwracać naturze wykorzystany pod budowę obszar. Zagospodarowanie terenu w postaci podjazdów, miejsc parkingowych i ścieżek może być stworzone z użyciem materiałów przepuszczających wodę. Fasada budynku może zostać wykonana w formie wertykalnego ogrodu. Możemy zastosować zielone lub niebieskie stropodachy. Dodatkowe inwestycje mające na celu wspieranie i wzbogacanie

5 https://www.ar.tum.de/en/gtla/research/experimental-buildings/baubotanik-tower/ (dostęp: 16.12.2020). 


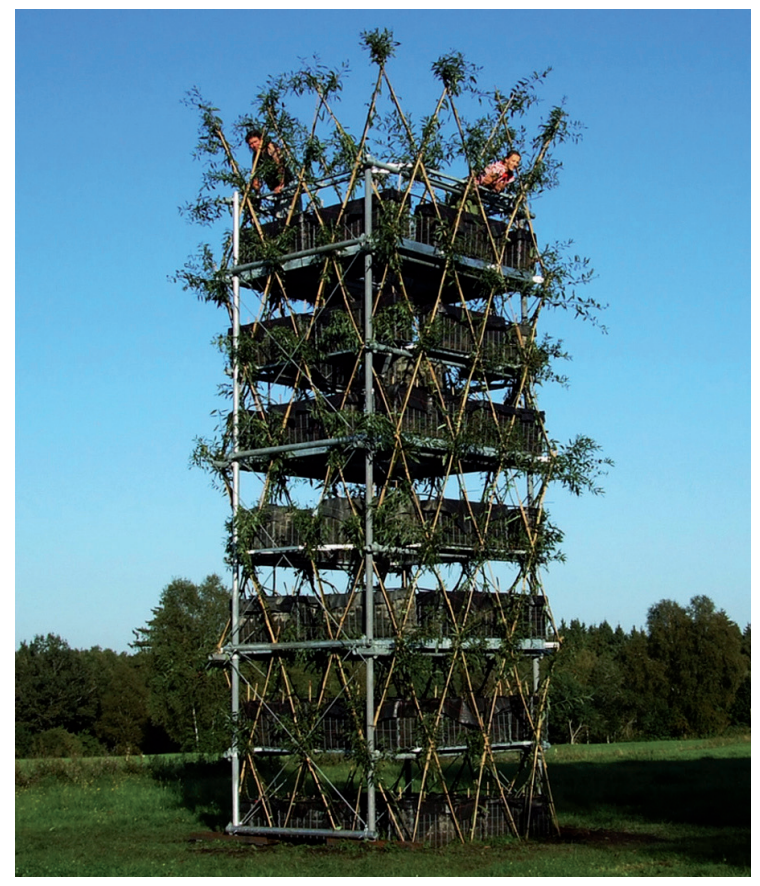

II. 6. Baubotanik Tower, arch.: Ferdinand Ludwig, Cornelius Hackenbrach (https://www.ar.tum.de/en/gtla/research/experimental-buildings/baubotanik-tower/)

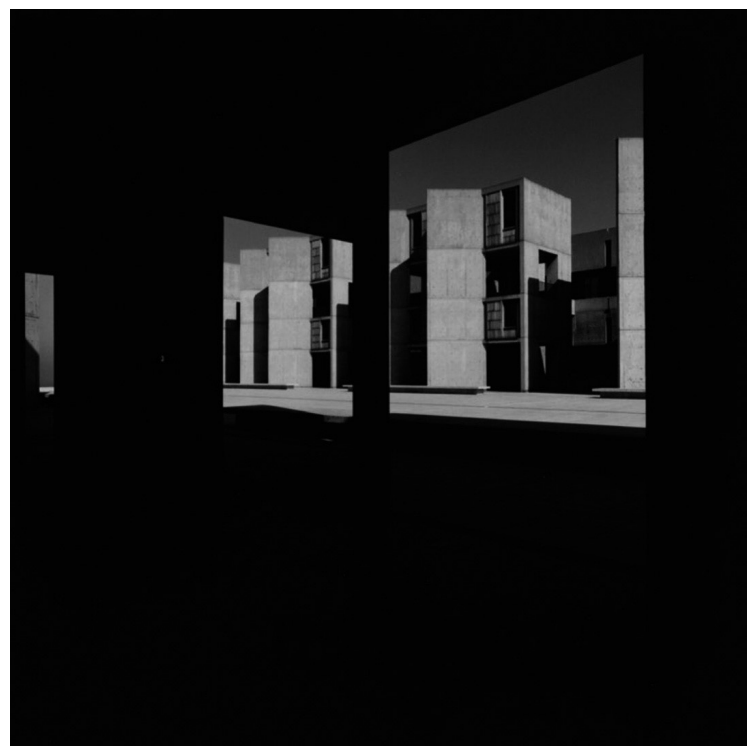

II. 7. Instytut Salka, La Jolla, Kalifornia, USA; arch.: Louis Kahn. Proj. R. Schezen 
świata owadów, na przykład przez projekty uli lub farm motyli, także są „zadośćuczynieniem” za zajmowanie przez człowieka terenów siedlisk. Czasami te rozwiązania mogą się okazać niewystarczające. Wynika to stąd, że architekt nie ma odpowiedniej wiedzy przyrodniczej na temat życia fauny i flory. W takim przypadku rozwiązaniem będzie współpraca z biologami i inżynierami środowiska. Projekt zespołu mieszkalnego Fælledby grupy Henning Larsen w Kopenhadze (il. 9) opierał się na takiej współpracy. Wszystkie budynki dla tego osiedla zaprojektowano w technologii drewnianej, co pozwoliło na stworzenie dodatkowych siedlisk zakomponowanych w fasadach. W sumie dla całości założenia, o wielkości 18 hektarów, udało się zachować $40 \%$ terenu w stanie nietkniętym ${ }^{6}$.

II. 8. Parlament Bangladeszu, Dhaka, Bangladesz; arch.: Louis Kahn; wystawa Architecture, Silence and Light. Louis Kahn in The Photographs by Roberto Schezen. Fot. autor
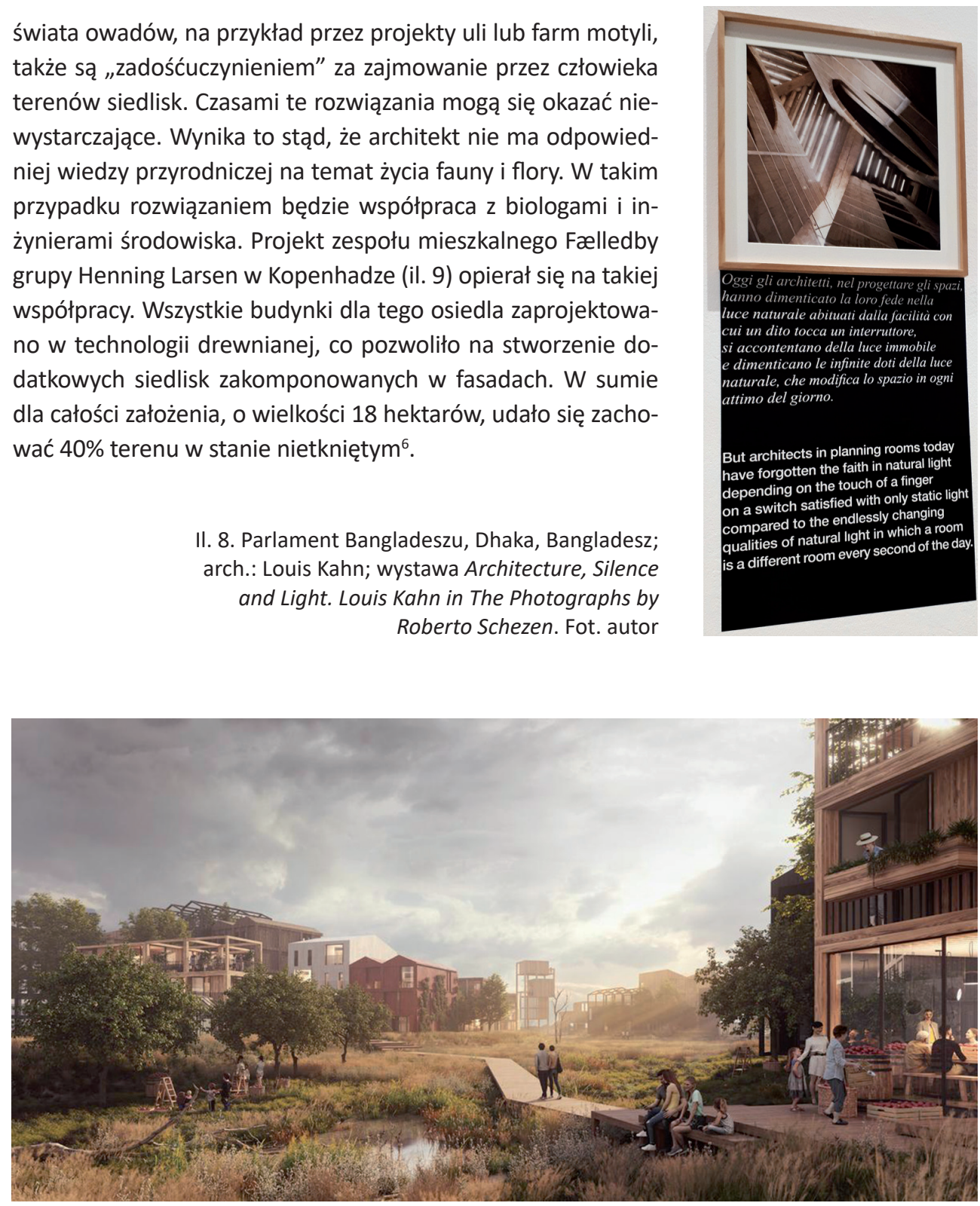

II. 9. Projekt zespołu mieszkalnego Fælledby grupy Henning Larsen w Kopenhadze. Wizualizacja: Vivid Vision

6 https://www.archdaily.com/931546/henning-larsen-to-design-copenhagens-first-all-timber-neighborhood (dostęp: 16.04.2021). 


\subsection{PROPONOWANE ROZWIAZZANIA DLA ŚWIERKOCINA}

Świerkocin jest dobrą lokalizacją dla nowych ośrodków turystycznych. Jest to związane z jego dogodną pod tym względem lokalizacją oraz opisanymi wysokimi walorami przyrodniczymi. Projektowana tu architektura powinna odpowiadać zasadom nurtu green architecture, a nawet proponować rozwiązania eksperymentalne. Ciekawym rodzajem zabudowy, jaka mogłaby powstać w tym miejscu, jest ekologiczne gospodarstwo o profilu agroturystycznym. W ramach prac dyplomowych inżynierskich, a także związanego z nimi konkursu na projekt „Siedliska w Świerkocinie”, zorganizowanego przez inwestorów - Beatę Kozicką i Marka Kozickiego, powstało wiele interesujących koncepcji. Zaproponowana przez uczestników architektura spełniała zarówno wymagania dotyczące ochrony przed zanieczyszczeniem świetlnym, jak i zanieczyszczeniem krajobrazu. Projekty wykorzystywały światło naturalne jako element kompozycji, ale też jako źródło dodatkowej energii (il. 10-11). W ich formie oraz wykończeniu elewacji zastosowano naturalne materiały oraz struktury zielone (il. 12).

\section{PODSUMOWANIE}

Inspirując się choćby częścią przedstawionych powyżej rozwiązań, możemy stworzyć przyjazny środowisku projekt. Świerkocin to mała miejscowość, ale o dużej potrzebie świadomej architektury. Z pozoru mogłoby się wydawać, że zaprojektowanie budynku w praktycznie nienaruszonej przestrzeni jest proste. Głębsza analiza środowiskowa pokazuje jednak, że istnieje wiele aspektów, które w tym i podobnych miejscach należy wziąć pod uwagę. Wnioski i założenia projektowe, wynikające z przedstawionych zagrożeń przyrodniczych, są bardzo konkretne. Na ich podstawie możemy wyróżnić dodatkowe etapy projektowe, które powinniśmy uwzględnić, aby zachować równowagę ekologiczną. Są to między innymi: analiza przyrodnicza, odnalezienie potencjalnych zagrożeń, specjalistyczna konsultacja i wreszcie propozycja zrównoważonych rozwiązań, wykorzystujących światową wiedzę na dany temat. Przykład miejscowości Świerkocin pokazuje, jak znaczący wpływ może mieć architekt na zachowanie naturalnego stanu przyrodniczego okolicznych siedlisk, zaczynając od małych elementów projektowych takich jak oprawy lamp, kończąc zaś na kompleksowych rozwiązaniach całych zespołów budynków przyjaznych środowisku. 


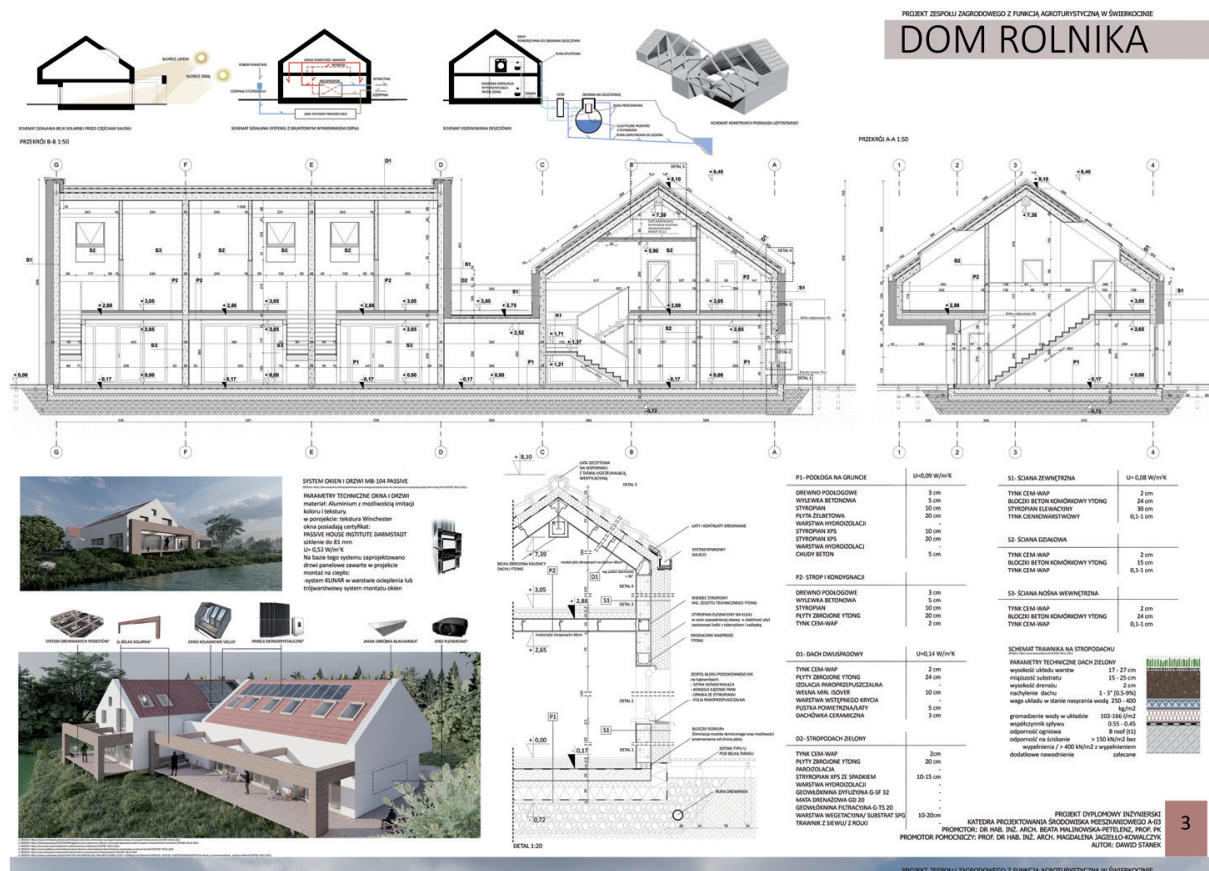

DOM ROLNIKA

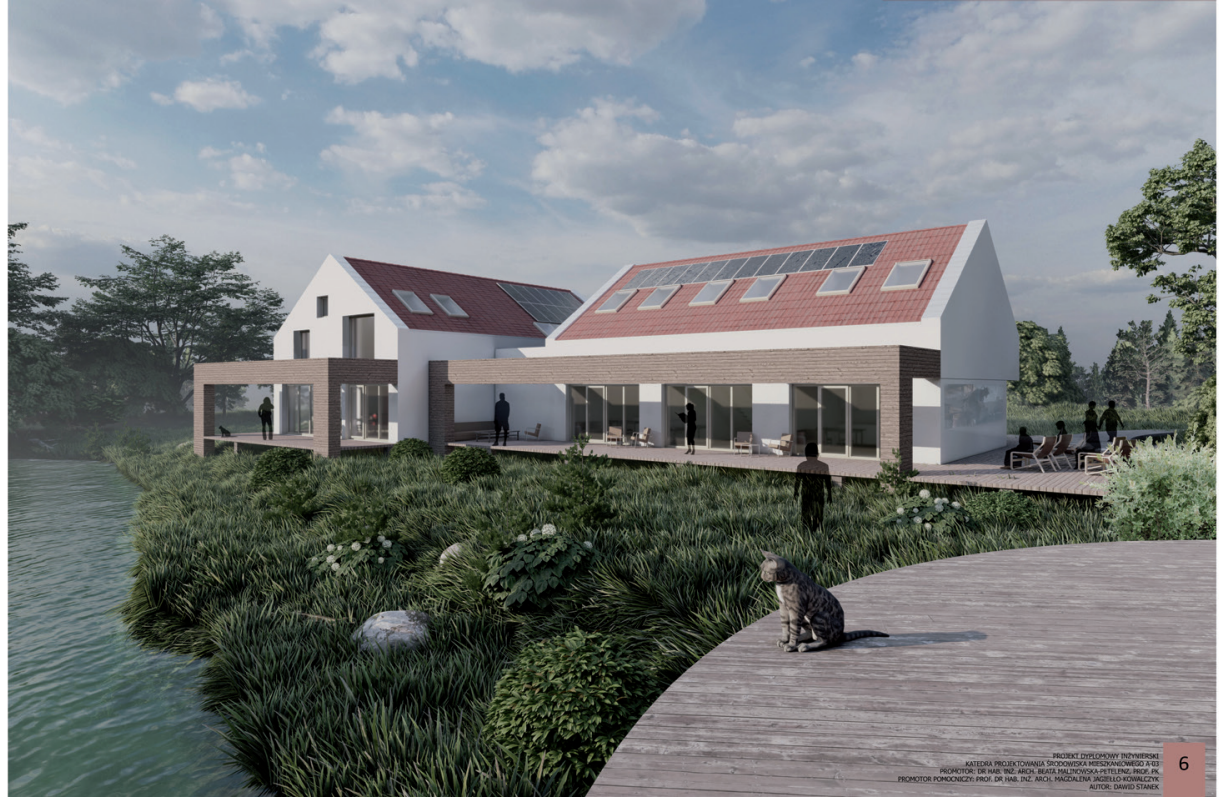

II. 10-11. Fragment projektu konkursowego „Siedlisko w Świerkocinie”: Dom rolnika - zabudowa zagrodowa z funkcją agroturystyczną w Świerkocinie - III miejsce. Proj. D. Stanek 


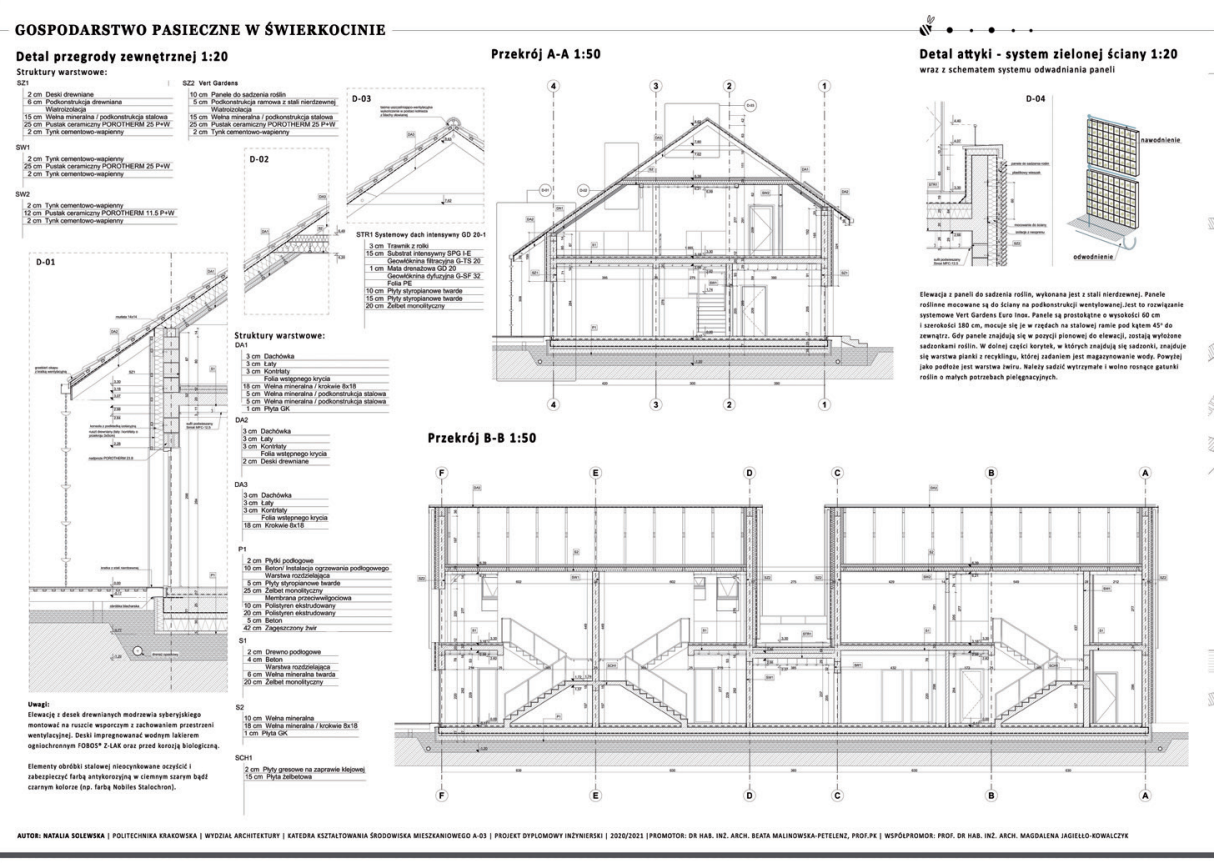

GOSPODARSTWO PASIECZNE W SWIERKOCINIE

Wizualizacje

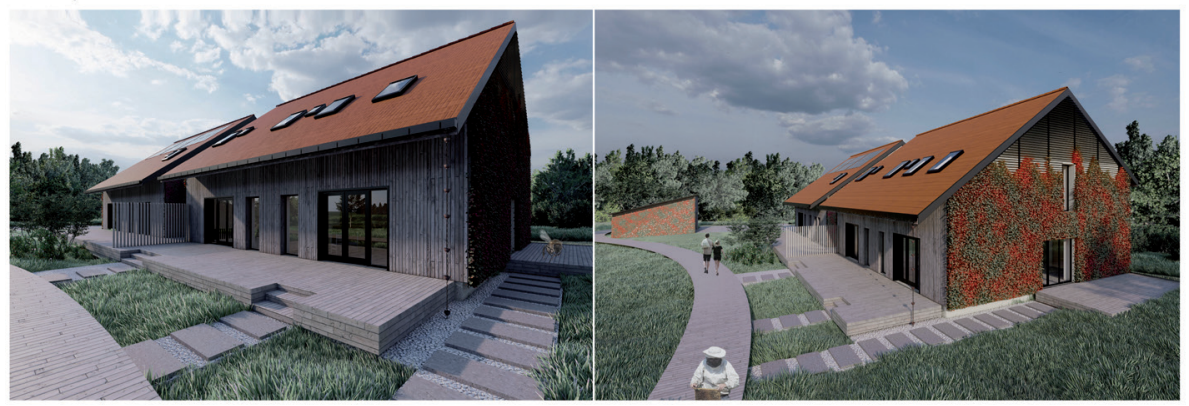

Elewacje 1:100 E-PD

E-Z
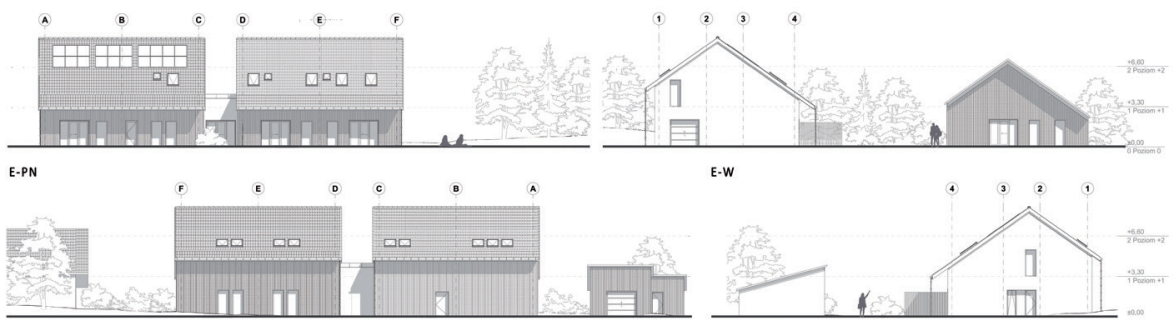

II. 12. Fragment projektu konkursowego „Siedlisko w Świerkocinie”: Gospodarstwo pasieczne z funkcją agroturystyczną w Świerkocinie - wyróżnienie. Proj. własny 


\section{BIBLIOGRAFIA}

Bobrowski, C. (2021). Fizyka. Krótki kurs. Warszawa: Wydawnictwo Naukowe PWN.

Frampton, K. (2017). W stronę krytycznego regionalizmu. Autoportret, 2, 11-21.

Konwencja o różnorodności biologicznej, sporządzona w Rio de Janeiro dnia 5 czerwca 1992 r. (2002). Dz.U. 2002, Nr 184, poz. 1532.

Kuźniewski, B. (2007). Olsztynek. Miasto i gmina. Olsztynek: Towarzystwo Przyjaciół Olsztynka. Marcinowska, S., Tęgowska, E. (2015). Oddziaływanie światła o różnym spektrum na bezkręgowce zmierzchu i pełnego dnia. Kosmos, 4, 589-597.

Siedlecki, B. (2016). Wpływ rozwiązań technologicznych systemów oświetlenia obszarów mieszkaniowych na socjologię oraz zanieczyszczenie światłem środowiska naturalnego. Środowisko Mieszkaniowe. Housing Environment, 17, 125-130.

Studium uwarunkowań i kierunków zagospodarowania przestrzennego gminy Olsztynek (2020). Załącznik nr 1. Uchwała Rady Miejskiej Nr XXII-209/2020.

Tałanda, J. (2015). Ekologiczne zanieczyszczenie światłem, czyli kiedy sztuczne światło w nocy zaburza naturalny cykl światła i ciemności w ekosystemie. Kosmos, 4, 611-616.

Tryjanowski, P., Dajdok, Z., Kujawa, K., Kałuski, T., Mrówczyński, M. (2011). Zagrożenia różnorodności biologicznej w krajobrazie rolniczym: czy badania wykonywane w Europie Zachodniej pozwalają na poprawną diagnozę w Polsce?. Polish Journal of Agronomy, 7, 113-119.

https://www.ar.tum.de/en/gtla/research/experimental-buildings/baubotanik-tower/ (dostęp: 16.12.2020).

https://www.archdaily.com/931546/henning-larsen-to-design-copenhagens-first-all-timber-neighborhood (dostęp: 16.04.2021).

https://www.archilovers.com/projects/215005/shilda-winery.html (dostęp: 16.04.2021). http://encyklopedia.warmia.mazury.pl (dostęp: 14.12.2020).

https://www.maxxi.art/en/events/louis-kahn-nelle-fotografie-di-roberto-schezen/ (dostęp: 16.12.2020).

https://olsztynek.pl/miasto-i-gmina-olsztynek/przyroda/fauna-i-flora/ (dostęp: 7.12.2020). https://planowanie.olsztynek.pl/ (dostęp: 7.12.2020). https://www.sciencedaily.com/releases/2019/11/191118162938.htm (dostęp: 7.12.2020). 
